\title{
ANALYSIS OF WATER QUALITY STATUS USING METHOD OF WATER POLLUTION INDEX: A CASE STUDY ON THE DENDENG RIVER
}

\section{Suwari ${ }^{1}$}

${ }^{1}$ Faculty of Science and Engineering, Nusa Cendana University, Jl. Adisucipto Kampus Baru Penfui, Kupang, NTT 85361, Indonesia

Received 6 May 2021

Accepted 20 May 2021

Published 31 May 2021

Corresponding Author

Suwari, suwari_chem68@yahoo.c om

DOI $10.29121 /$

granthaalayah.v9.i5.2021.3937

Funding: This research received no specific grant from any funding agency in the public, commercial, or not-for-profit sectors.

Copyright: (C) 2021 The Author(s). This is an open access article distributed under the terms of the Creative Commons Attribution License, which permits unrestricted use, distribution, and reproduction in any medium, provided the original author and source are credited.

OPEN

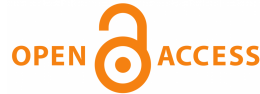

\section{ABSTRACT}

The Dendeng River is vital for economic sustainability and viability for the community, industry and commerce around the flood plain of the river as well as raw water sources of the Kupang PDAM. However, increased domestic and industrial waste disposal along the river has caused severe pollution. One way to maintain the quality of the river is by continuously monitoring the pollutants and applying technology control as well as controlling strategy. The aim of the research mainly is to establish the water quality status of Dendeng River by water pollution Index method based on parameter physics and chemistry, i.e. $\mathrm{pH}, \mathrm{DO}, \mathrm{COD}, \mathrm{BOD}, \mathrm{TSS}, \mathrm{TDS}, \mathrm{NH}_{3}-\mathrm{N}, \mathrm{NO}_{2}-\mathrm{N}, \mathrm{NO}_{3}-\mathrm{N}$, and $\mathrm{PO}_{4}-\mathrm{P}$. The research was carried out based on field survey and sample examined in situ and in laboratory. The removal of water sample from Dendeng River conducted based on composite sampling as many as six-point locations of Dendeng River as representative of upstream up to downstream zone. The quality status of Dendeng River is in good condition to lightly polluted with a pollution index value of 0.6 to 1.52. Value of the DO, BOD, COD, and phosphate content were higher than the allowable class 1 standard. The Water Quality Index value of Dendeng River was 86.67 , which is included in the good water quality class.

Keywords: Dendeng River, Pollution Index, Water Quality Index, Water Quality Status

\section{INTRODUCTION}

Water is one of the natural resources which has a very important function for human life and livelihood, as well as for advancing the general welfare, so it is basic capital and main factor of development. Therefore, water resources must be protected so that they can be properly utilized by humans and other living things. Scarcity and difficulty in obtaining clean and suitable water has become a problem that has started to emerge in many places and has become more prevalent from year to year, including 
in Indonesia. Indonesia has $6 \%$ of the world's water supply or about $21 \%$ of the Asia Pacific water supply Lingkungan and Hidup (2004), however, the tendency of water consumption to increase exponentially while the availability of clean water continues to decrease rapidly due to natural degradation and pollution which is estimated to be 15-35\% per capita per year Lingkungan and Hidup (2008). This condition is exacerbated by the limited ability to access and predict: water availability, water quality, and water use and balance Kehutanan (2020).

Apart from facing the problem of the criticality of river water which is judged by the magnitude of the maximum and minimum water flow fluctuations, the water quality of rivers in Indonesia has also decreased a lot due to pollution. As a result, clean water is limited. The results of water quality monitoring at 537 monitoring points in 78 rivers in Indonesia in 2019 carried out by the Ministry of Environment and Forestry showed that the content of Biochemical Oxygen Demand (BOD), Chemical Oxygen Demand (COD), phosphate ( $\mathrm{P}-\mathrm{PO}_{4}{ }^{3-}$ ), fecal coli and total coliform of more than $50 \%$ parameters monitored did not meet to criteria for class I water quality with the water quality index (WQI) value dropping from 72.77 points in 2018 to 52.62 points in 2019 Simonovic (2002).

Dendeng River is one of 35 important rivers in Indonesia. Apart from having a role as a city center, Dendeng River is also used for various needs, including to supply clean water to the people of Kupang City. The rapid development of Kupang City has resulted in changes in community activities and land use along the Dendeng River, which was originally a forest area turned into a residential area and the loss of green lines. Increased disposal of domestic waste, agricultural waste, livestock waste and household industry along the Dendeng River has caused a decrease in carrying capacity and assimilative capacity of the Dendeng River. If this condition is not controlled, it will have ecological, economic and social impacts on the community and require greater recovery costs.

Determining status of water quality is one of the first steps in the process of monitoring and preventing the decline in water quality in the Dendeng River. Through this study it can be seen that water quality conditions indicate polluted or good conditions in a water source so that prevention, control and recovery efforts in case of pollution can be carried out optimally according to the level of pollution.

There are many ways to monitor the status of water quality in a water source. The environmental quality standard method, which is carried out by comparing water quality parameters with water quality standards, is unable to describe the aggregate water quality. Likewise, the use of water quality modeling requires in-depth knowledge of hydraulics and hydrodynamics as well as rigorous validation Pesce (2000). In this study, the determination of the water quality status of the Dendeng River was carried out using Pollution Index based on the results of the analysis of physical and chemical parameters. This method is able to provide an aggregate value from the measurement results of many water quality parameters in a simple and easy to interpret way. The main objective of this study was to determine the quality sta- 
tus and quality index of Dendeng River water based on $\mathrm{pH}$, total of suspended solids (TSS), total of dissolved solids (TDS), oxygen demand (DO), chemical oxygen demand (COD), biological oxygen demand (BOD), ammonia- $\mathrm{N}\left(\mathrm{NH}_{3}-\mathrm{N}\right)$, nitrate- $\mathrm{N}\left(\mathrm{NO}_{3}-\mathrm{N}\right)$, nitrite- $\mathrm{N}\left(\mathrm{NO}_{2}-\mathrm{N}\right)$, and phosphate-P $\left(\mathrm{PO}_{4}-\mathrm{P}\right)$.

\section{MATERIALS AND METHODS}

\subsection{CHEMICALS AND RESEARCH EQUIPMENT}

Chemicals used in this study were: sodium hydroxide, sulfuric acid, sodium sulfite, ammonium chloride, borate buffer solution, sodium phenolate solution, sodium hypochlorite solution, potassium dichromate, silver sulfate, feroin indicator, ferrous ammonium sulfate, sulfamic acid, manganese chloride, potassium iodide, sodium thiosulfate standard solution, Nessler reagent, brucine, sodium chloride solution, sodium nitrite, distilled water, sulfanilamide solution, N-(1-naphthyl)ethylenediamine dihydrochloride, ammonium molybdate, stannum chloride standard solution, and indicator phenolptalein, while equipment used includes: a set of glassware and titration tools for water chemistry analysis, Van Dorn water sampler, coolbox, thermometer, pHmeter, and spectrophotometer.

\subsection{LOCATION AND SAMPLE COLLECTION}

Determining location of sampling water from the Dendeng River was carried out by purposive sampling. Water sampling is done using a composite method that is a mixture of several samples in one stream from several points of collection with the same volume and time, so that the method is expected to represented water conditions of all depth levels at each observation station. Determining location for water sampling takes into account the following:

1. Basically, Dendeng River is the main river which empties into Kupang Bay. As the main river, the Dendeng River receives water from its tributaries. The tributaries of Dendeng River included the Air Nona River, the Kapadala River, the Bakunase River and the Sembunyi River.

2. River water sampling was carried out at six point locations: two sampling points in the upstream zone, three points in the middle zone, and one point in the downstream zone. Locations and coordinates of Dendeng River water sampling are shown in Table 1.

Table 1 Location and coordinates of sampling

\begin{tabular}{llll}
\hline Sampling Point & Sampling locations & \multicolumn{2}{c}{ Koordinat } \\
\hline Point 1 & S & E \\
Point 2 & Haukoto River in Fatukoa Village & $10^{0} 13^{\prime} 01,5^{\prime \prime}$ & $123^{0} 36^{\prime} 09,0^{\prime \prime}$ \\
\hline Point 3 & Sembunyi River in Bakunase Village & $10^{0} 12^{\prime} 01,1^{\prime \prime}$ & $123^{0} 34^{\prime} 53,5^{\prime \prime}$ \\
Point 4 & Air Nona River in Airnona Village & $10^{0} 10^{\prime} 26,0^{\prime \prime}$ & $123^{0} 35^{\prime} 02,3^{\prime \prime}$ \\
\hline & Sembunyi River in Nunleu Village & $10^{0} 10^{\prime} 24,8^{\prime \prime}$ & $123^{0} 35^{\prime} 03,0^{\prime \prime}$ \\
\hline
\end{tabular}




\begin{tabular}{llll}
\hline Table 1 continued & & & \\
\hline Point 5 & Dendeng Dam in Nunleu Village & $10^{0} 10^{\prime} 17,4^{\prime \prime}$ & $123^{0} 34^{\prime} 59,8^{\prime \prime}$ \\
Point 6 & Selam Bridge in Airmata Village & $10^{0} 09^{\prime} 48,9^{\prime \prime}$ & $123^{0} 34^{\prime} 38,2^{\prime \prime}$
\end{tabular}

\subsection{ANALYSIS OF PHYSICAL AND CHEMICAL PARAMETERS OF WATER}

DO and pH levels were measured in situ, while other parameters, namely: TSS, TDS, COD, BOD, $\mathrm{NH}_{3}-\mathrm{N}, \mathrm{NO}_{2}-\mathrm{N}, \mathrm{NO}_{3}-\mathrm{N}$ and $\mathrm{PO}_{4}$-P were analyzed in the laboratory. Methods and equipment used for laboratory analysis of the Dendeng River water samples are shown in Table 2 .

\begin{tabular}{ccccc}
\hline \multicolumn{5}{l}{ Table 2 Water quality parameters and analysis methods } \\
\hline S.N. & Parameters & Unit & $\begin{array}{c}\text { Analysis } \\
\text { Methods }\end{array}$ & Equipment \\
\hline 1. & TSS & $\mathrm{mg} / \mathrm{L}$ & Gravimetry & Analytical balance \\
\hline 2. & $\mathrm{TDS}$ & $\mathrm{mg} / \mathrm{L}$ & Gravimetry & Analytical balance \\
\hline 3. & $\mathrm{pH}$ & - & Potensiometry & pHmeter \\
\hline 4. & $\mathrm{DO}$ & $\mathrm{mg} / \mathrm{L}$ & Winkler titration & Titrationequipment \\
\hline 5. & $\mathrm{COD}$ & $\mathrm{mg} / \mathrm{L}$ & Titrimetri & Titrationequipment \\
\hline 6. & $\mathrm{BOD}$ & $\mathrm{mg} / \mathrm{L}$ & Titrimetri & Titrationequipment \\
\hline 7. & Ammonia-N & $\mathrm{mg} / \mathrm{L}$ & Spectrophotometry & Spectrophotometer \\
\hline 8. & Nitrite-N & $\mathrm{mg} / \mathrm{L}$ & Spectrophotometry & Spectrophotometer \\
\hline 9 & Nitrate-N & $\mathrm{mg} / \mathrm{L}$ & Spectrophotometry & Spectrophotometer \\
\hline 10. & Phosphate-P & $\mathrm{mg} / \mathrm{L}$ & Spectrophotometry & Spectrophotometer \\
\hline
\end{tabular}

\subsection{ANALYSIS OF WATER QUALITY STATUS WITH POLLUTION INDEX}

Determination level of water pollution in Dendeng River relative to the permissible water quality parameters refers to the Minister of Environment Decree No. 115 of 2003, using the Pollution Index (PI) method. This method can directly relate level of contamination with whether or not the river can be used for certain uses and with the value of certain parameters. Steps for determining the level of pollution using Pollution Index are:

1.Select parameters if the parameter value is low, the water quality will improve;

2.Select the concentration of quality standard parameters that do not have a range;

3.Calculate the $\mathrm{Ci} / \mathrm{Lij}$ value for each parameter at each sampling location;

4. a. If value concentration of parameter decreases, it indicates that the level of contamination has increased, for example, DO. Determine the theoretical value or maximum value of $\mathrm{C}_{i m}$ (for DO, $\mathrm{C}_{i m}$ is the saturated $\mathrm{DO}$ value); In this case the measured $\mathrm{C}_{i} / \mathrm{L}_{i j}$ value is replaced by the calculated $\mathrm{C}_{i} / \mathrm{L}_{i j}$ value, that is: $(\mathrm{C} / \mathrm{L})=$

b. If the default Lij has a range, then:

- For $\mathrm{C} \leq$ Lon average, then: 


$$
\left(\mathrm{C}_{\mathrm{i}} / \mathrm{L}_{\mathrm{i}}\right)_{\mathrm{new}}=\frac{C_{\mathrm{im}}-C_{i(\text { menawement result })}}{C_{\mathrm{im}}-L_{i j}}
$$

- For C > Lon average, then:

For $\mathrm{C}_{\mathrm{i}} \leq \mathrm{L}_{\mathrm{ij}}$ on averkage, then: $\left(\mathrm{C}_{\mathrm{i}} / \mathrm{L}_{\mathrm{ij}}\right)_{\text {new }}=\frac{\left[C_{i}-\left(L_{i j}\right)_{\text {average }}\right]}{\left\{\left(L_{i j}\right)_{\min }-\left(L_{i j}\right)_{\text {average }}\right\}}$

c. If two values $\left(\mathrm{C}_{i} / \mathrm{L}_{i j}\right)$ are adjacent to the reference value that is 1.0 , for example $\mathrm{C}_{1} / \mathrm{L}_{1 j}=0.9$ and $\mathrm{C}_{2} / \mathrm{L}_{2 j}=1.1$ or the difference is very large, for example $\mathrm{C}_{3} / \mathrm{L}_{3 j}=5.0$ and $\mathrm{C}_{4} / \mathrm{L}_{4 j}=10.0$, so the level of water pollution is difficult to determine. The ways to overcome this difficulty are:

- Using the measured value $\left(\mathrm{C}_{i} / \mathrm{L}_{i j}\right)$ if this value $<1.0$

- Using a new value of $\left(\mathrm{C}_{i} / \mathrm{L}_{i j}\right)$ if the measured value of $\left(\mathrm{C}_{i} / \mathrm{L}_{i j}\right)$ is greter than 1.0, that is: $\left(\mathrm{C}_{i} / \mathrm{L}_{i j}\right)_{\text {new }}=1.0+5 \cdot \log \left(\mathrm{C}_{i} / \mathrm{L}_{i j}\right)_{\text {measurement result }}$;

5. Find the (Ci/Lij R and (Ci/Lij M values of the whole $\mathrm{Ci} / \mathrm{Lij}$;

6.Determine the Pollution Index (PI value using the following formula:

$$
\text { For } \mathrm{C}_{\mathrm{i}}>\mathrm{L}_{\mathrm{i}} \text { on average, then: }\left(\mathrm{C}_{\mathrm{i}} / \mathrm{L}_{\mathrm{i}}\right)_{\mathrm{new}}=\frac{\left[C_{i}-\left(L_{i j}\right)_{\text {average }}\right]}{\left\{\left(L_{i j}\right)_{\max }-\left(L_{i j}\right)_{\text {average }}\right\}}
$$

where: PI is pollution index, $\mathrm{C}_{i}$ is concentration of water quality parameters (i), $\mathrm{L}_{i j}$ is water quality standards, $\left(\mathrm{C}_{i} / \mathrm{L}_{i j}\right)_{R}$ is the average value of $\mathrm{C}_{i} / \mathrm{L}_{i j},\left(\mathrm{C}_{i} / \mathrm{L}_{i j}\right)_{M}$ is the maximum value of $\mathrm{C}_{i} / \mathrm{L}_{i j}$.

\section{Table 3 Water Quality Status Based on the Pollution Index}

\begin{tabular}{ccc}
\hline No & PI & Quality status \\
1. & $0 \leq \mathrm{PI} \leq 1.0$ & Meet quality standards \\
2. & $1.0<\mathrm{PI} \leq 5.0$ & Lightly polluted \\
3. & $5.0<\mathrm{PI} \leq 10$ & Moderately polluted \\
4. & $\mathrm{IP}>10$ & Heavily polluted \\
\hline
\end{tabular}

Based on the pollution index data, then the Water Quality Index (WQI) is determined using the following criteria:

1. If the Pollution Index is less than 1, then the Water Quality Index will be given a score of 100 .

2. If the Pollution Index is in the range of $1<\mathrm{PI} \leq 4.67$, then the Water Quality Index is given a score of 80 . 
3. If the Pollution Index is in the range of $4,67<\mathrm{PI} \leq 6,32$, then the Water Quality Index is given a score of 60.

4. If the Pollution Index is in the range of $6,32<\mathrm{PI} \leq 6,88$, then the Water Quality Index is given a score of 40 .

5. If the Pollution Index is greater than 6,88, then the Water Quality Index is given a score of 20.

The Dendeng River water quality index as a whole is calculated from the average water quality index for all samples.

\section{RESULTS AND DISCUSSION}

\subsection{DEGREE OF ACIDITY}

Degree of acidity $(\mathrm{pH})$ is an important parameter in monitoring water quality and determining the value of water use for household, irrigation, aquatic organisms and other interests. $\mathrm{pH}$ value shows the level of acidity or strength of acids and bases in water. $\mathrm{pH}$ value affects solubility and form of chemical compounds in water bodies. Changes in $\mathrm{pH}$ will affect changes and biological activity of water organisms. According to Ok et al. (2008), the growth of aquatic organisms can take place well in the $\mathrm{pH}$ range of 6.5 to 8.2. The results showed that $\mathrm{pH}$ value of Dendeng River water fluctuates from the upstream, middle and downstream zones, but is still in normal water $\mathrm{pH}$ range, namely $\mathrm{pH} 6$ to 9 . The average $\mathrm{pH}$ value of the Dendeng River water ranges from 7.09 to 7.67, with an overall average value of 7.35. Fluctuation in $\mathrm{pH}$ value in river water according to Sa et al. (2008) is influenced by several things, including (i) organic matter or organic waste. Increasing in acidity is influenced by organic materials which release $\mathrm{CO}_{2}$ if they undergo a decomposition process, (ii) inorganic materials or inorganic waste. Inorganic industrial wastewater generally contains high amounts of mineral acids so that its acidity is also high, (iii) alkaline and alkaline salts in water, (iv) acid rain due to gas emissions.

In general, $\mathrm{pH}$ of Dendeng River water meets the Class I of National Water Quality Standard according to Government Regulation Number 22 of 2021 which requires a $\mathrm{pH}$ value from 6 to 9. Figure 1 shows $\mathrm{pH}$ variation of Dendeng River waters at each observation point during the period from May to August 2020.

Fluctuation in $\mathrm{pH}$ value at each observation point can be caused by difference in measurement time and effect of entering pollutants is also fluctuating. Average $\mathrm{pH}$ value of Dendeng River water at the six observation points was 7.35 which means it was slightly alkaline. This can occur due to the chemical composition of the waters which may contain large amounts of limestone which comes from eroding rocks in the river. In addition, the high domestic waste due to the use of detergents by the community during bathing and washing activities in the river also contributes to the alkaline nature of Dendeng River waters. 


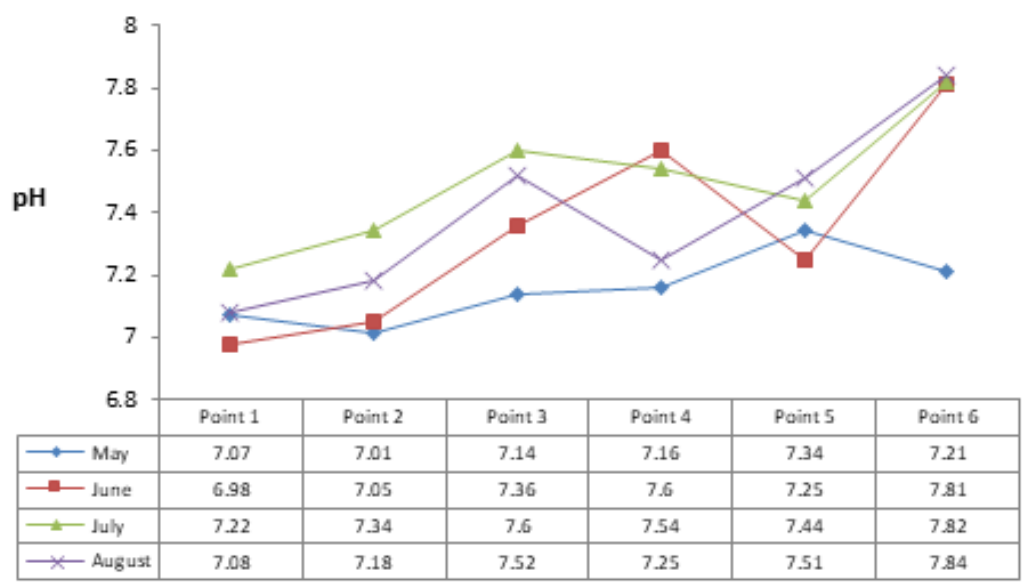

Figure 1 Profile of Dendeng River baseon $\mathrm{pH}$ parameters

\subsection{TOTAL OF SUSPENDED SOLIDS}

Suspended solids contain both organic and inorganic matter. Results showed that the value of total suspended solids (TSS) in the waters of Dendeng River ranged from 4.1 to $21.5 \mathrm{mg} / \mathrm{L}$, with an overall average value of $9.4 \mathrm{mg} / \mathrm{L}$. High levels of TSS in Dendeng River are caused by a large number of suspended particles consisting of silt and fine sand as well as microorganisms, especially those caused by soil erosion that is carried into water bodies or due to deposition and decay of organic material from residential waste and industry. According to Alam et al. (2007), increasing in TSS value was caused by the presence of increased silt and clay particles in river water. The TSS level of Dendeng River is shown in Figure 2.

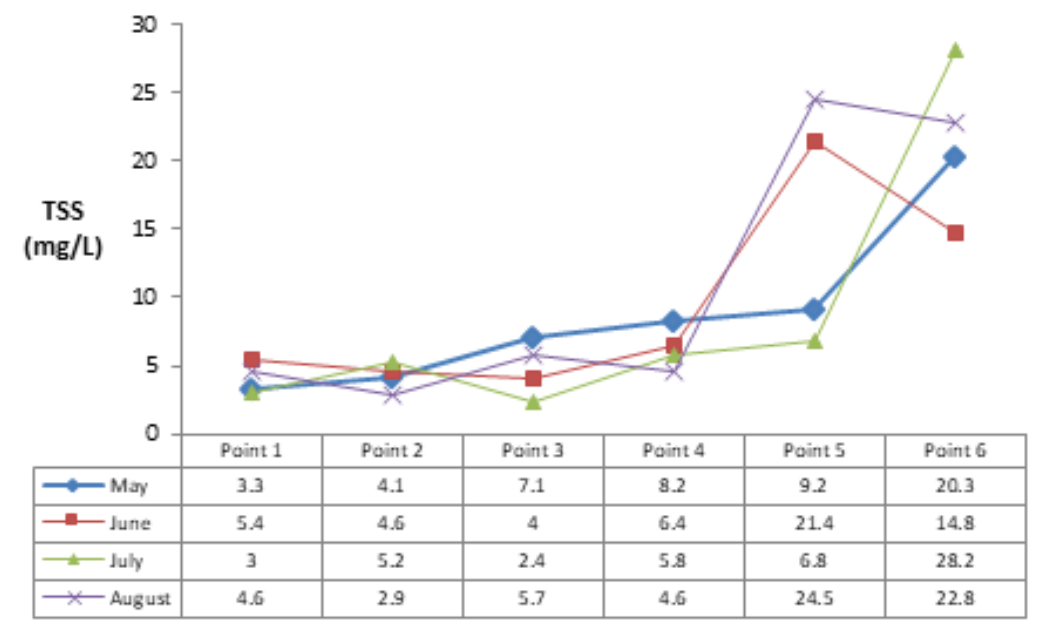

Figure 2 TSS levels in Dendeng River water 
The National water quality standards (NWQS) according to Government Regulation Number 22 of 2021 (attachment VI) stipulates that maximum level of TSS allowed in the use of class 1 water is $40 \mathrm{mg} / \mathrm{L}$. Thus, in general Dendeng River is suitable for use as a source of raw drinking water. High levels of suspended solids can cause a decrease in the rate of photosynthesis so that the primary productivity of waters decreases and food chain will be disrupted. According to Oa et al. (2008), high suspended solids will affect aquatic biota in two ways. First, blocking and reducing the intensity of sunlight into water bodies, so that process of photosynthesis is inhibited. This condition will reduce the dissolved oxygen levels in the water body. Second, high TSS levels can disrupt aquatic biota such as fish because they are filtered by gills.

\subsection{TOTAL OF DISSOLVED SOLIDS}

Total of dissolved solids (TDS) are solids that have a smaller size than suspended solids. Dissolved solids consist of inorganic and organic compounds dissolved in water that are not filtered with millipore filter paper with a pore size of $0.45 \mu \mathrm{m}$. Results showed that the average TDS level at each observation point ranged from 241 to $284 \mathrm{mg} / \mathrm{L}$, with an overall average value of $263 \mathrm{mg} / \mathrm{L}$. Based on the class 1 of NWQS, the maximum TDS content is $1000 \mathrm{mg} / \mathrm{L}$. Thus, TDS level of Dendeng River water meets the required quality standards so that it is suitable for use as a source of raw water for drinking water. Level of TDS at six sampling points are shown in Figure 3 .

Based on the data (Figure 3 ), it appears that TDS content is much higher than that of TSS. This shows that the solids that entering to the waters of the Dendeng River are more small solids (dissolved solids) or solids originating from organic waste and inorganic materials in the form of ions. For example, wastewater containing detergents and water-soluble surfactants from household and industrial waste.

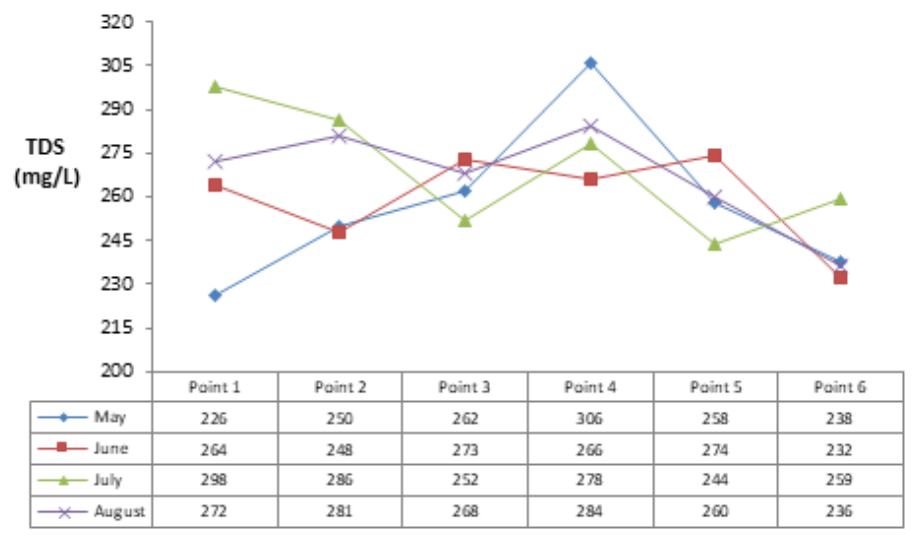

Figure 3 TDS levels in Dendeng River water 


\subsection{DISSOLVED OXYGEN}

Dissolved oxygen (DO) is a key water quality parameter that describes condition of water freshness. The higher the concentration of DO, the better the water quality. DO levels indicate the amount of dissolved oxygen in water or indicate oxygen status in water bodies Raja et al. (2008). DO levels in natural waters are usually less than 10 $\mathrm{mg} / \mathrm{L}$. DO levels in waters contaminated with organic matter will decrease because oxygen molecules in the water are used by microorganisms to decompose of organic materials. Excessive organic pollution will be increasing activity of decomposing microorganisms, which will cause anoxic. In this condition, the decomposition of organic matter takes place anaerobically to produce methane gas $\left(\mathrm{CH}_{4}\right)$, ammonia $\left(\mathrm{NH}_{3}\right)$ or hydrogen sulfide $\left(\mathrm{H}_{2} \mathrm{~S}\right)$.

Results showed that DO levels in the waters of the Dendeng River ranged from 6.1 to $7.3 \mathrm{mg} / \mathrm{l}$, with an overall average value of $6.8 \mathrm{mg} / \mathrm{L}$. DO levels in the upstream and middle zones are higher than in the downstream zone. DO levels in the downstream zone are lower, indicating that the river conditions in the downstream zone are more polluted mainly by organic matter Sa et al. (2008), Aa et al. (2006). Domestic waste and agricultural waste as well as industrial effluent are the main causes of high levels of pollution in the downstream zone of the river. According to Jc et al. (2010) stated that DO levels that support the life of aquatic organisms are at least $5 \mathrm{mg} / \mathrm{L}$. If DO levels in the waters drop below $2 \mathrm{mg} / \mathrm{L}$, it will cause death in many fish species. Dendeng River water quality data based on DO parameters is shown in Figure 4 .

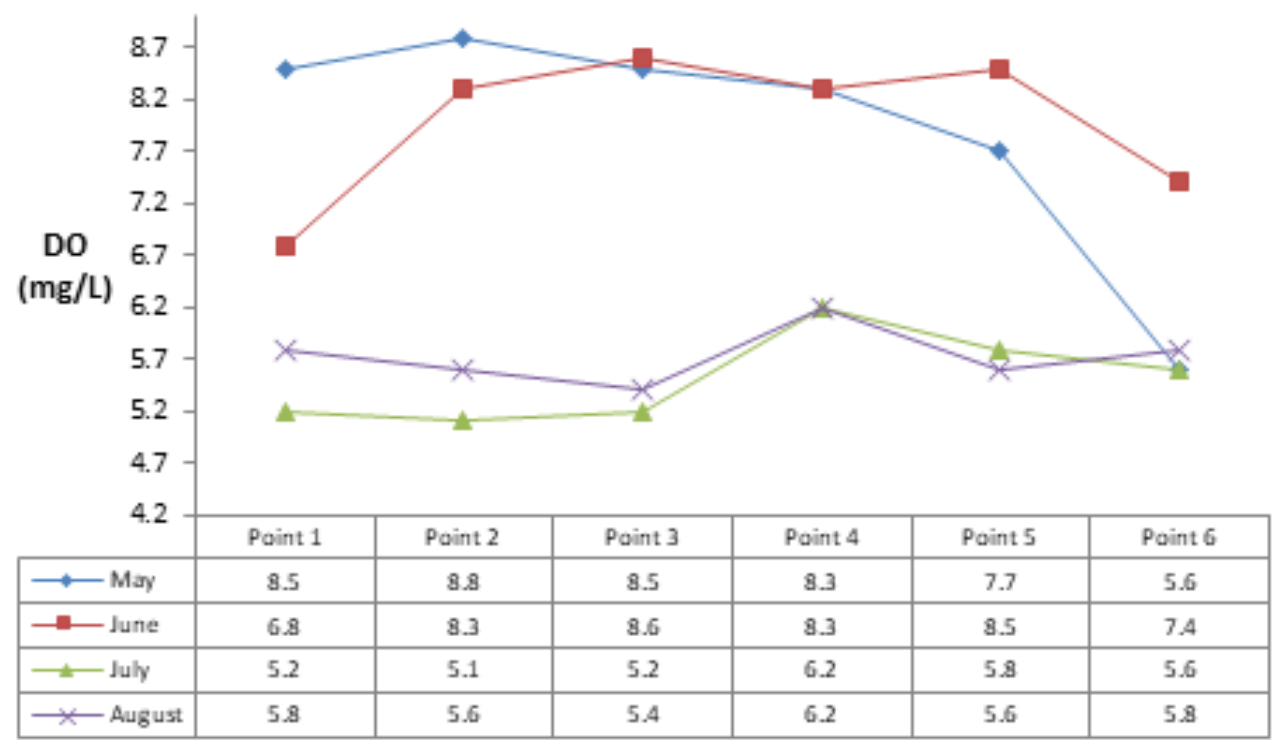

Figure 4 DO level in Dendeng River water

Dissolved oxygen levels fluctuated between observation periods (Figure 4 ), presumably due to the mixing process and movement of water masses (turbulence), pho- 
tosynthetic activity, respiration and influence of waste (effluent) entering water bodies. In general, DO levels of Dendeng River meet the criteria for water quality class 1 according to the NSWQ which requires a minimum DO level of $6 \mathrm{mg} / \mathrm{L}$. Decreasing in DO levels can occur due to the addition of a large amount of organic pollution load, which is caused by the discharge of liquid waste that exceeds the ability of river self-purification and presence of chemicals that can be oxidized by oxygen.

\subsection{BIOLOGICAL OXYGEN DEMAND}

Biological oxygen demand (BOD) is a measure of the amount of oxygen needed to degrade organic material into simpler compounds, such as $\mathrm{CO}_{2}$ and $\mathrm{H}_{2} \mathrm{O}$. BOD levels are used to indicate organic pollution in the waters. High BOD levels indicate that the waters contain lots of organic matter. It was found that BOD levels between points and observation periods varied widely (Figure 5 ).

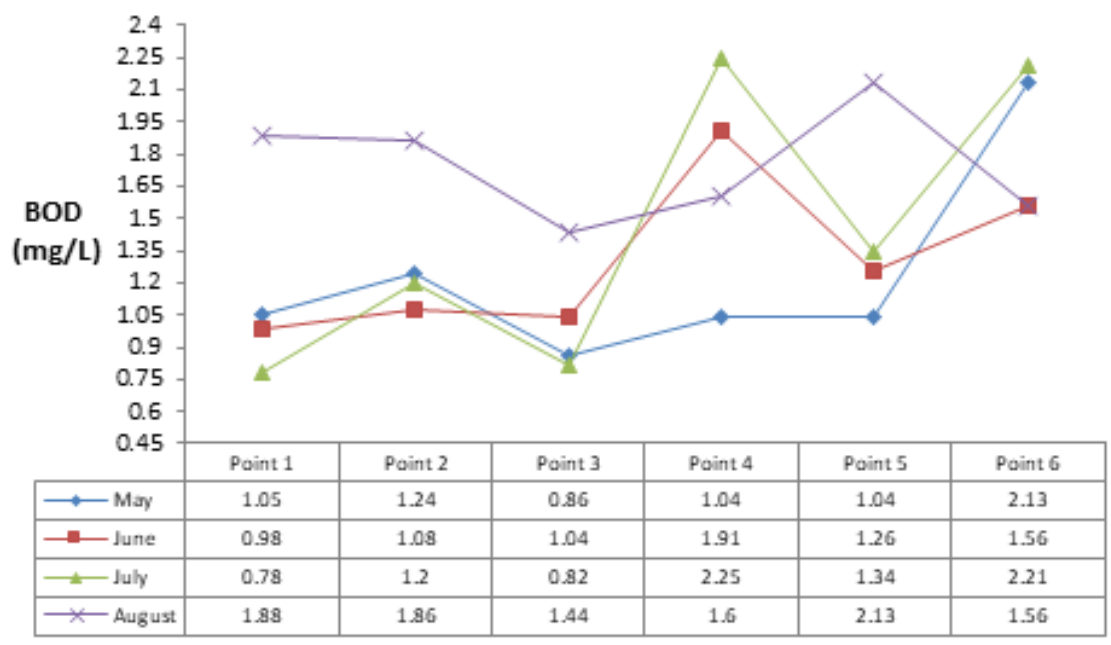

Figure 5 BOD level in Dendeng River water

The results showed that the average BOD levels ranged from 1.04 to $1.87 \mathrm{mg} / \mathrm{L}$, with an overall average value of $1.43 \mathrm{mg} / \mathrm{L}$. BOD level in the downstream zone of the Dendeng River has exceeded the NSQW which requires a maximum BOD level of 2 $\mathrm{mg} / \mathrm{L}$. According to Sa et al. (2008), high levels of BOD directly reflect the high activity of microorganisms in the water and indirectly indicate the high content of suspended organic matter. In general, it was found that BOD levels did not always increase from upstream to downstream zones. This is reinforced by Jfn and Adi (2009) which states that the BOD value in general does not differ significantly between seasons and segments of the river. 


\subsection{CHEMICAL OXYGEN DEMAND}

Chemical Oxygen Demand (COD) indicates the total amount of oxygen needed to chemically oxidize both biodegradable and non-biodegradable of organic materials. The COD parameter can be used as a measure for water pollution by organic materials which can naturally be oxidized through microbiological processes and result in reduced DO levels in water. Results study of COD levels in waters of the Dendeng River are presented in Figure 6.

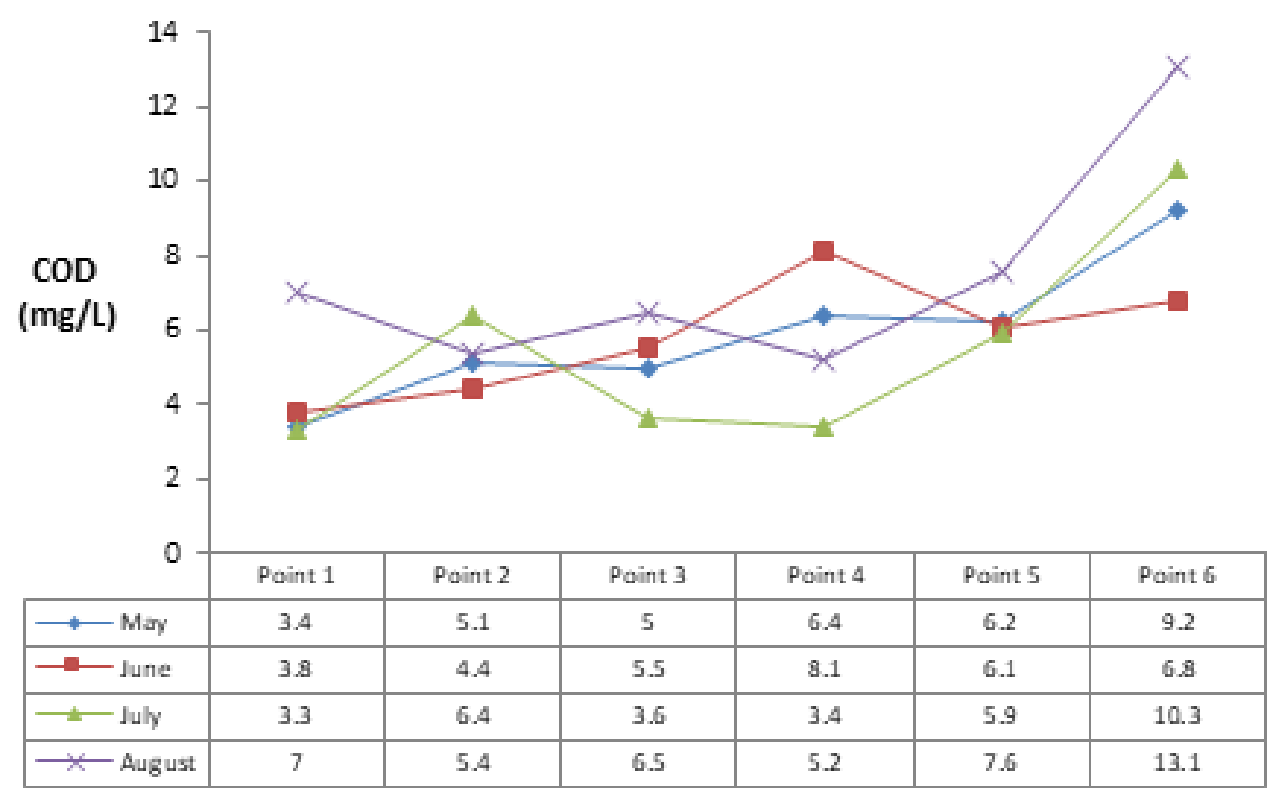

Figure 6 COD level in Dendeng River water

The results showed that COD levels at the six monitoring points ranged from 4.35 to $9.85 \mathrm{mg} / \mathrm{L}$, with an overall mean level of $6.1 \mathrm{mg} / \mathrm{L}$. Overall, waters of the Dendeng River in terms of COD levels are still feasible as a source of raw drinking water based on the Class 1 threshold according to the NSWQ which requires a maximum COD level of $10 \mathrm{mg} / \mathrm{L}$. Ratio of the mean levels of $\mathrm{BOD}_{5}$ and COD was 0.24. According to Alaerts et al. (1984), this ratio shows that in waters of the Dendeng River, apart from being polluted by organic materials that are biodegradable, there are also nonbiodegradable materials. This is confirmed by Raja et al. (2008), which states that a COD value that is greater than that of BOD indicates the presence of materials that can be chemically oxidized, especially non-biodegradable materials.

\subsection{NITRITE}

Naturally, the presence of nitrite $\left(\mathrm{NO}_{2}{ }^{-}\right)$in water is very small and the amount is much smaller than nitrate, because nitrite is quickly oxidized to nitrate, according to the following reaction: 


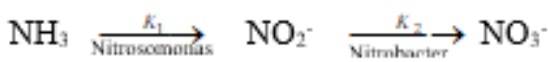

In general, the nitrite content in water is very low because nitrite is unstable in the presence of oxygen. Nitrite ions are present in water as an intermediate oxidation state of nitrogen, which is an intermediate form between ammonia and nitrate (nitrification) and between nitrate and nitrogen gas (denitrification). The presence of nitrite in water illustrates the biological degradation process of organic matter with very low dissolved oxygen levels Rawat and Joshi (2019). According to Effendi (2003), sources of nitrite can be industrial waste and domestic waste. Nitrite levels in the water are relatively small because this substance is immediately oxidized to nitrate.

It was found that nitrite levels (as $\mathrm{N}$ or $\mathrm{NO}_{2}-\mathrm{N}$ ) in waters of the Dendeng River ranged from 0.002 to $0.017 \mathrm{mg} / \mathrm{L}$, with an overall average level of $0.009 \mathrm{mg} / \mathrm{L}$. Figure 7 shows the distribution of the average $\mathrm{NO}_{2}-\mathrm{N}$ levels of the Dendeng River at six monitoring points representing the upstream, middle and downstream zones of the Dendeng River.

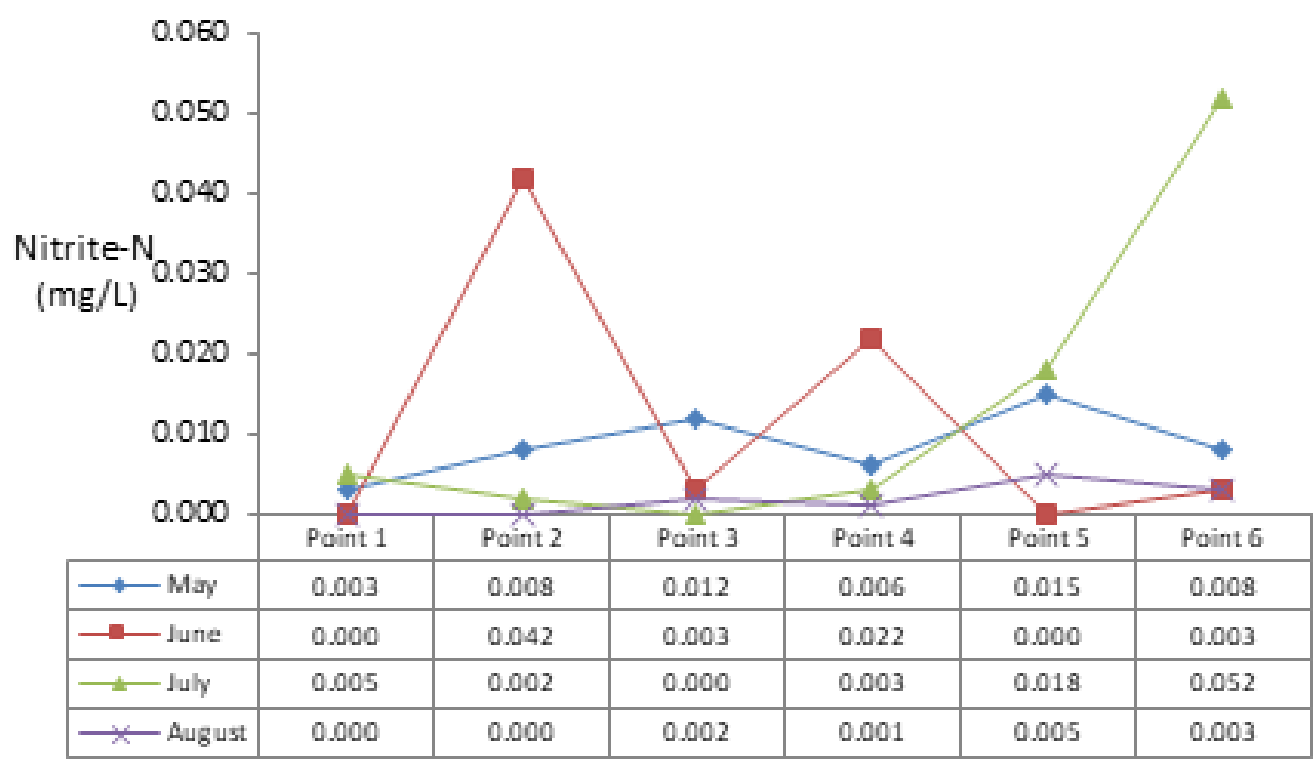

Figure 7 Nitrite level in Dendeng River water

In general, nitrite levels in waters of the Dendeng River meet the class 1 water quality standard threshold according to the NSWQ which requires a maximum nitrite level of $0.06 \mathrm{mg} / \mathrm{L}$. Thus, it can be concluded that the Dendeng River in terms of the nitrite (as $\mathrm{N}$ ) parameter is suitable for use as a source of raw water for drinking water. In natural waters, nitrite level is about $0.001 \mathrm{mg} / \mathrm{L}$ and does not exceed than $0.06 \mathrm{mg} / \mathrm{L}$. Nitrite levels greater than $0.05 \mathrm{mg} / \mathrm{L}$ can be toxic to very sensitive aquatic organisms. WHO sets the maximum nitrite level in drinking water at $1.0 \mathrm{mg}$ 
/ L. Meanwhile, the levels of nitrite that are allowed in the human body are from 0.00 to $0.06 \mathrm{mg} / \mathrm{kg}$ of body weight. Excessive intake of nitrites can result in obstruction of the work of hemoglobin in carrying oxygen through the blood. According to Rizza (2013), nitrite will react with hemoglobin to form methemoglobin (MetHb) so that it interferes with the oxygen-binding process (especially in infants), due to the oxidation of Fe (II) to Fe (III) in hemoglobin. Fe (II) ion which is classified as forming blood so it is called haem iron, while Fe (III) ion is not a blood generator (non haem iron). Oxidation of Fe (II) can reduce the ability of red blood cells to carry oxygen.

\subsection{AMMONIA}

Ammonia compounds $\left(\mathrm{NH}_{3}\right)$ in water are the result of the reduction of nitrate or nitrite compounds and decomposition of organic materials containing $\mathrm{N}$ such as protein. Meanwhile, ammonium $\left(\mathrm{NH}_{4}{ }^{+}\right.$) is formed at $\mathrm{pH}<7$ (acidic) and becomes ammonia at $\mathrm{pH}>7$ (alkaline). Ammonia levels are higher with increasing water depth and decreasing dissolved oxygen levels. Ideally, the level of ammonia in water is less than $0.1 \mathrm{mg} / \mathrm{L}$

Results analysis of ammonia (as N) levels, the average for each monitoring point ranged from 0.023 to $0.071 \mathrm{mg} / \mathrm{L}$ with an overall average of $0.040 \mathrm{mg} / \mathrm{L}$. Based on class 1 water quality criteria according to the NSWQ which requires a maximum ammonia level of $0.1 \mathrm{mg} / \mathrm{L}$, in terms of ammonia parameters, the Dendeng River is still suitable for use as a source of drinking water raw water. The ammonia content at the six monitoring points is shown in Figure 8.

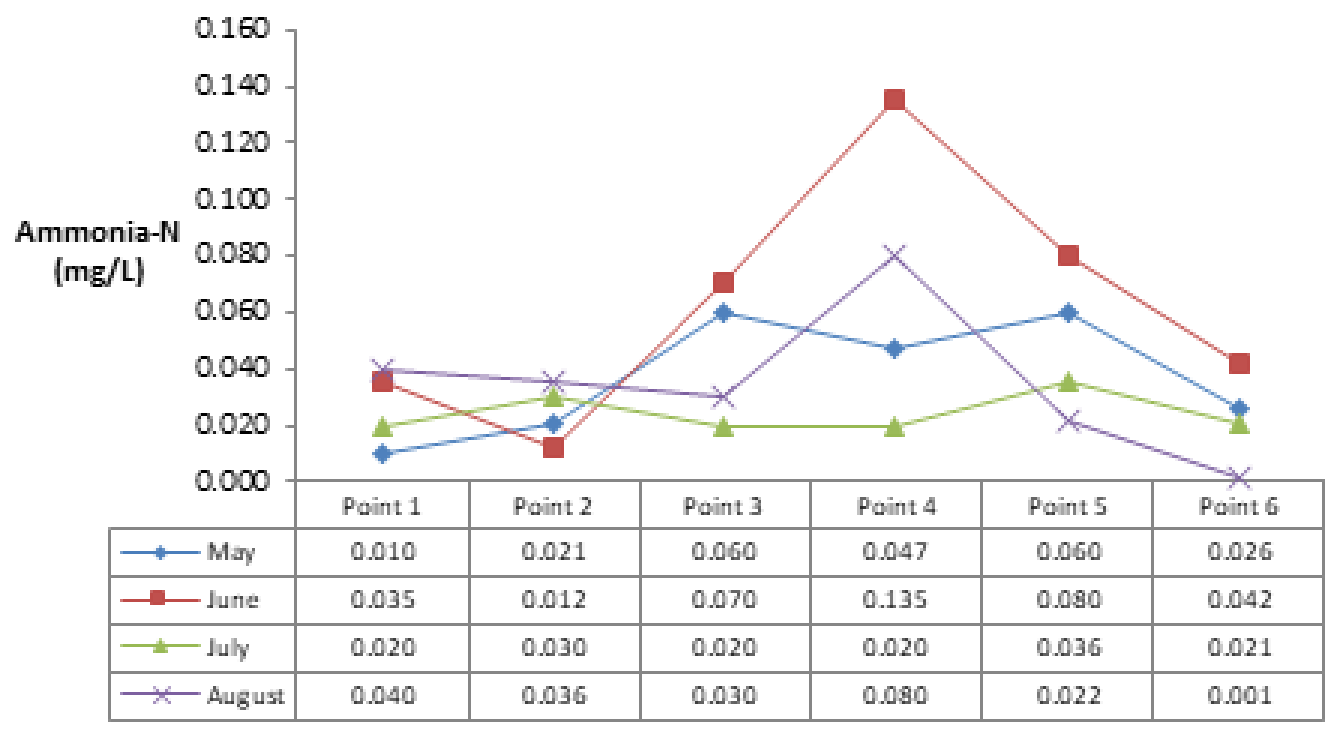

Figure 8 Ammonia level in Dendeng River water

In river waters such as Dendeng River, ammonia can be sourced from urine and feces as well as results of microbiological oxidation of organic matter $\left(\mathrm{H}_{a} \mathrm{O}_{b} \mathrm{C}_{c} \mathrm{~N}_{d}\right)$ 
found in natural water or industrial and domestic effluent, according to the following reaction:

$$
\mathrm{H}_{2} \mathrm{O}_{2} \mathrm{C}_{1} \mathrm{~N}_{\mathrm{d}}+(\mathrm{c}+1 / 4 \mathrm{a}-1 / 2 \mathrm{~b}-3 / 4 \mathrm{~d}) \mathrm{O}_{2} \stackrel{\text { backera }}{\longrightarrow} \mathrm{c} \mathrm{CO}_{2}+\mathrm{H} / 2(\mathrm{a}+3 \mathrm{~d}) \mathrm{H}_{2} \mathrm{O}+\mathrm{d} \mathrm{NH}
$$

The ammonia compound in water is in equilibrium with the ammonium ion. This equilibrium is influenced by $\mathrm{pH}$ and temperature. Ammonia is gaseous, so the stability of ammonia in water is greatly influenced by temperature. The equilibrium reaction is described as follows:

$$
\mathrm{NH}_{3}+\mathrm{H}_{2} \mathrm{O} \hookrightarrow \mathrm{NH}_{4}^{+}+\mathrm{OH}^{-}
$$

When $\mathrm{pH}$ is less than 7 , the equilibrium reaction will shift to the left so that the ammonia $\left(\mathrm{NH}_{3}\right)$ level increases, while in acidic conditions $(\mathrm{pH}<7)$, the equilibrium reaction will shift to the right so that the nitrogen content in the water is dominant in the form of $\mathrm{NH}_{4}{ }^{+}$. Ammonia is toxic to aquatic organisms. Toxicity of ammonia to aquatic organisms is influenced by pH, DO levels, and temperature Effendi (2003). At low $\mathrm{pH}$, ammonia will be toxic if the levels are high, while at high $\mathrm{pH}$, ammonia will be toxic even though the levels are low. Decreasing DO levels will increase the toxicity of ammonia in water.

\subsection{NITRATE}

Nitrate is a form of nitrogen compounds and nutrients essential for the growth, reproduction and life of organisms. According to Oa et al. (2008), nitrate compounds are formed as the end product of ammonia biochemical oxidation resulting from protein breakdown. Nitrate and nitrite content in river water is highly dependent on microbial transportation which also depends on DO levels. Nitrate contamination in surface water was significantly found in areas with high population and agricultural development areas Oa et al. (2008). Results showed that the average nitrate levels ranged from 0.42 to $1.05 \mathrm{mg} / \mathrm{L}$, with an overall mean level of $0.82 \mathrm{mg} / \mathrm{L}$. The presence of nitrate is thought to have come from the use of fertilizers on agricultural land near the river in the upstream zone of Dendeng River. This assumption is based on several reports of nitrate contamination in river water due to agricultural waste, domestic waste, and livestock waste as reported by Alam et al. (2007), Oa et al. (2008), and Raja et al. (2008). Results analysis of nitrate (as N) levels at six monitoring points of Dendeng River are shown in Figure 9 .

Nitrate levels in water are controlled by the nitrification process, which is process of changing ammonia to nitrite and then nitrate, according to the following reaction:

$$
\begin{aligned}
& 2 \mathrm{NH}_{3}+3 \mathrm{O}_{2} \stackrel{\text { Nitrosenonas }}{\longrightarrow} 2 \mathrm{NO}_{2}^{-}+2 \mathrm{H}^{+}+\mathrm{H}_{2} \mathrm{O}+\text { Energy } \\
& 2 \mathrm{NO}_{2}^{-}+\mathrm{O}_{2} \stackrel{\text { Nitrobacter }}{\longrightarrow} 2 \mathrm{NO}_{3}^{-}+\text {Energy }
\end{aligned}
$$




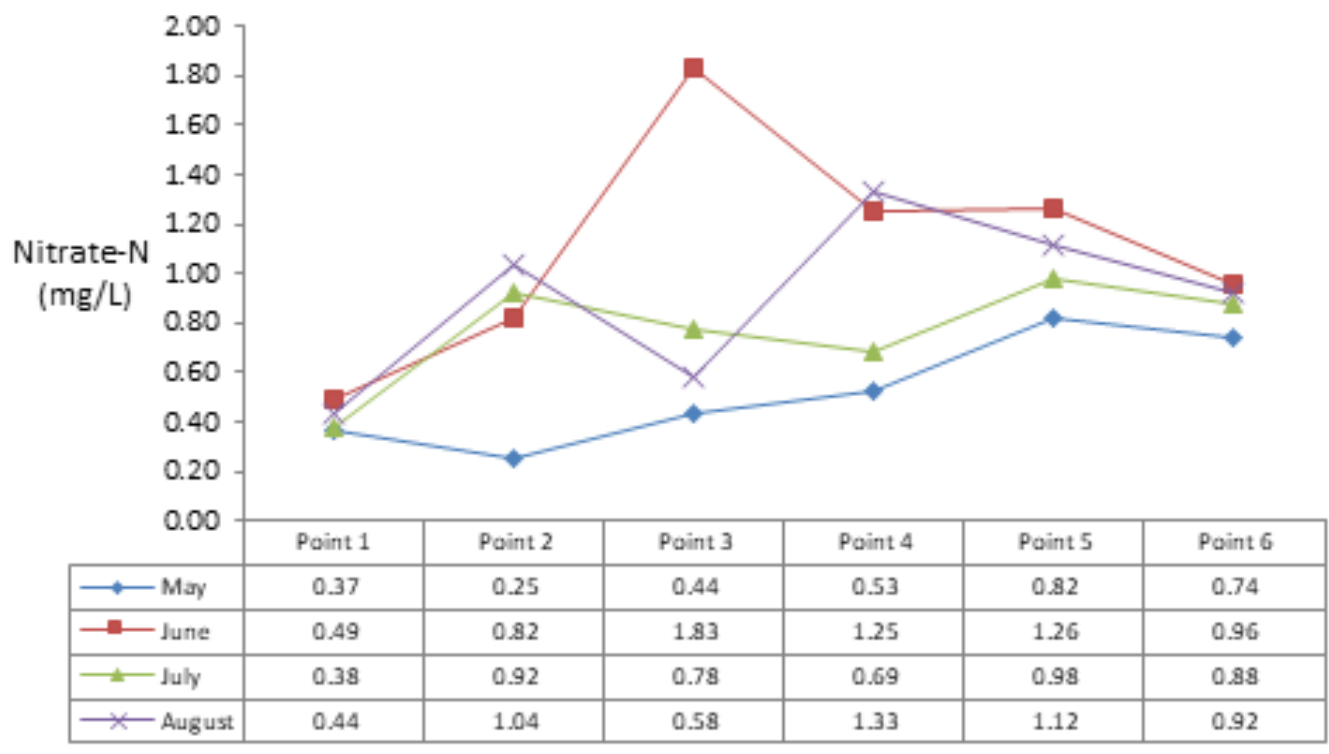

Figure 9 Nitrate level in Dendeng River water

Nitrification is a chemosynthetic reaction that utilizes nitrogenous bacteria. According to Novonty and Olem (1994), the factors that influence the nitrification reaction are $\mathrm{pH}$, dissolved oxygen levels, nitrifying bacteria, and temperature. In natural waters, nitrate levels are generally less than $0.1 \mathrm{mg} / \mathrm{L}$. Nitrate levels greater than $5 \mathrm{mg} / \mathrm{L}$ indicate anthropogenic contamination originating from human activities and animal feces, industrial waste, fertilizers and paints Effendi (2003). Like ammonia, the presence of nitrate ions in water is also closely related to ammonia and nitrite. Balancing that occurs is greatly influenced by free oxygen content in the water. When dissolved oxygen level is low, equilibrium moves towards ammonia, whereas when oxygen level is high, equilibrium moves towards nitrite. Thus, nitrate is the end product of nitrogen oxidation in water. Class 1 water quality standards according to Government Regulation No. 22 of 2021 (Attachment VI), requires a maximum nitrate level (as N) of $10 \mathrm{mg} / \mathrm{L}$.

\subsection{PHOSPHATE}

Phosphate compounds in water are in the form of orthophosphates, polyphosphates and organophosphates. Orthophosphate is a form of phosphate compound that is soluble in water, while other forms are not. The presence of these three forms of phosphate compounds in water is known as P-total. Orthophosphate is a form of phosphorus that can be used directly by aquatic plants, while polyphosphate must undergo hydrolysis to form orthophosphate before it can be used as a source of phosphorus. After entering the plant (eg phytoplankton), inorganic phosphate undergoes a change into organophosphate. Phosphate that binds to ferries $\left(\mathrm{Fe}_{2}\left(\mathrm{PO}_{4}\right)_{3}\right)$ is 
insoluble and settles on the bottom of the water. When anaerobic conditions occur, Fe(III) ions are reduced to Fe(II) ions, which dissolves and releases phosphate into the water, thereby increasing the presence of phosphate in the waters Effendi (2003).

Phosphates are undesirable anions in water, because their presence is a limiting factor for eutrophication and has negative effects on aquatic life. According to Ok et al. (2008), high phosphate and nitrate content in waters can cause eutrophocation, which increases algae growth and decreases dissolved oxygen content in water. Results showed that the average phosphate (as P) level at each monitoring point ranged from 0.14 to $0.33 \mathrm{mg} / \mathrm{L}$, with an overall average level of $0.25 \mathrm{mg} / \mathrm{L}$. Phosphate levels in the waters of Dendeng River are presented in Figure 10 .

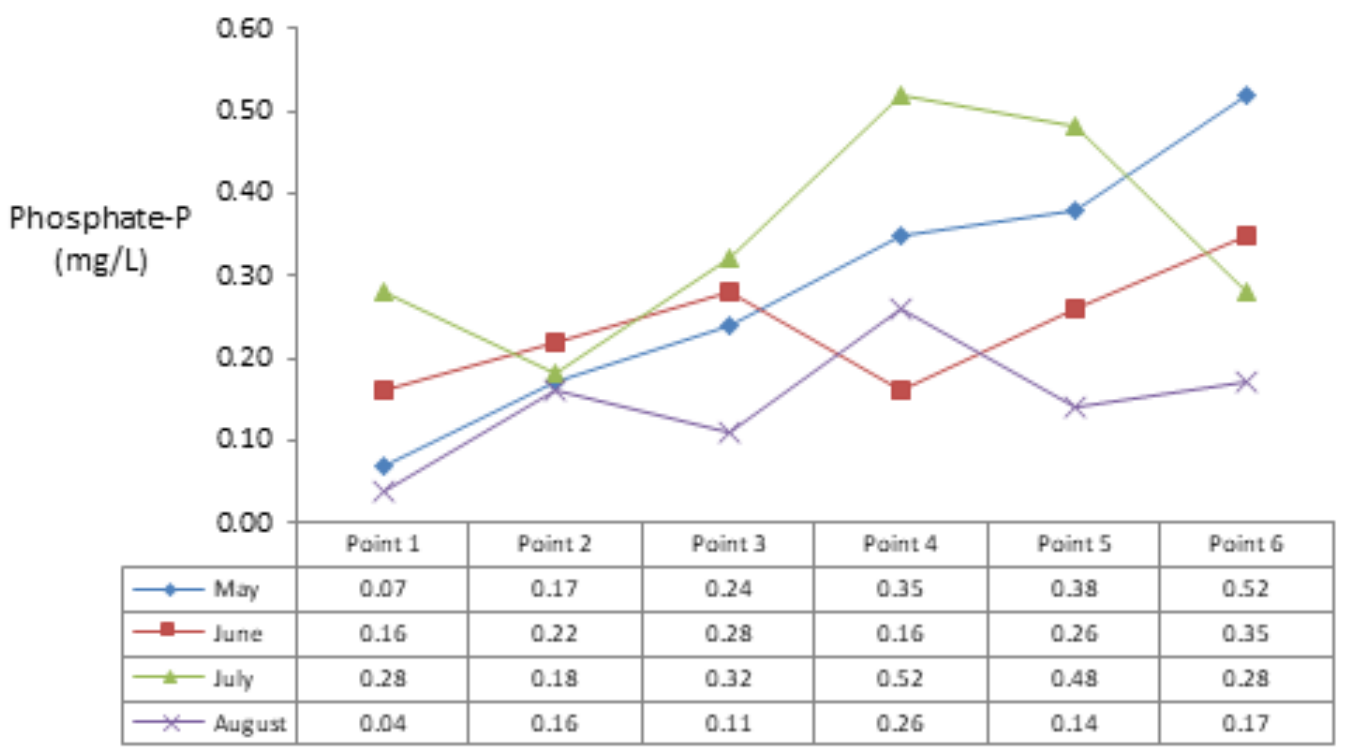

Figure 10 Phosphate level in Dendeng River water

The NSWQ requires the maximum phosphate content (as $\mathrm{P}$ ) for class 1 river water to be $0.2 \mathrm{mg} / \mathrm{L}$. Based on the NSWQ phosphate levels in the Dendeng River in the period May to August 2020, as many as four of the six monitoring points did not meet quality standards. The presence of phosphate in Dendeng River is thought to have originated from domestic waste and agricultural waste Alaerts et al. (1984). In agricultural areas (upstream zone - point 1) phosphate compounds come from fertilizers, which enter rivers through sewers and rainwater flows. Phosphates can enter rivers through resident wastewater using detergents that contain phosphates. The results of research by 0 a et al. (2008), stated that the presence of phosphate ions in river water is caused by the release of agricultural waste into rivers and the use of phosphate additives in detergent formulations $\left(\mathrm{Na}_{5} \mathrm{P}_{3} \mathrm{O}_{10}\right)$ which enter water bodies through domestic or urban waste. 


\subsection{WATER QUALITY STATUS}

The status of water quality indicates the polluted or good condition of a water source compared to the established water quality standards. In this research, the method used to determine the water quality status is the pollution index method. The assessment of the water quality condition of the Dendeng River was carried out by comparing the value of the measured water quality parameters with the NSWQ referring to Government Regulation Number 22 of 2021 (Attachment VI). Determining results of pollution index based on the physical and chemical parameters of water are shown in Table 4 .

\begin{tabular}{lccccc}
\hline \multicolumn{7}{l}{ Table 4 Pollution Index of Dendeng River } \\
\hline No. & Location & \multicolumn{2}{c}{$\mathbf{C}_{i} / \mathbf{L}_{i j}$} & PI & Quality status \\
\hline & Average & Maximum & & \\
\hline & Haukoto River & 0.27 & 0.80 & 0.60 & Meet quality standards Meet \\
\hline 2 & Sembunyi River & 0.31 & 0.90 & 0.67 & quality standards Lightly \\
\hline 3 & Air Nona River & 0.32 & 1.42 & 1.01 & polluted \\
\hline 5 & Sembunyi River Dendeng & 0.42 & 2.02 & 1.46 & Lightly polluted Lightly \\
\hline 6 & Dam & 0.42 & 2.02 & 1.46 & polluted \\
\hline
\end{tabular}

Based on the pollution index (Table 4), it appears that the Dendeng River has been polluted at a mild level by several chemical and physical parameters. It is also shows that the lowest level of pollution occurs in upstream zone with pollution index values of 0.60 and 0.67 . The highest pollution index value is in the downstream zone, namely at sampling point 6 with a pollution index value of 1.52 . Results analysis of the pollution index were used to determine the Dendeng River water quality index (WQI), the results of which are presented in Table 5 .

\begin{tabular}{lcccc}
\hline $\begin{array}{l}\text { Table } 5 \\
\text { River }\end{array}$ & River Water Quality (WQI)Index of Dendeng \\
\hline No. & Pollution Index & Amount & Weigthing & Value \\
\hline 1. & $\mathrm{PI} \leq 1.00$ & 2 & 100 & 200 \\
\hline 2. & $1.00<\mathrm{PI} \leq 4.67$ & 4 & 80 & 320 \\
\hline 3. & $4.67<\mathrm{PI} \leq 6.32$ & 0 & 60 & 0 \\
\hline 4. & $6.32<\mathrm{PI} \leq 6.88$ & 0 & 40 & 0 \\
\hline 5. & $\mathrm{PI}>6.88$ & 0 & 20 & 0 \\
\hline \multicolumn{5}{c}{ WQI Value } \\
\hline
\end{tabular}

The analysis result shows that the WQI value of Dendeng River was 86.67. According to the Horton model classification Uddin et al. (2021), the final value of the WQI is 86.67 , which is included in the good water quality class.

Based on the value of pollution index, it can be estimated that the limits of pollutant parameters that can cause the waters to be heavily polluted by using the equa- 
tion approach: $\left(\mathrm{C}_{i} / \mathrm{L}_{i j}\right)=1.0+5 . \log \left(\mathrm{C}_{i} / \mathrm{L}_{i j}\right)$. A body of water is heavily polluted if the IP value is more than 10 , thus, $10<\left(1.0+5 . \log \left(C_{i} / L_{i j}\right)\right.$. The solution to this equation gives a result $\left(\mathrm{C}_{i} / \mathrm{L}_{i j}\right)$ of about 63 . Based on this, the evaluation level of pollution using Pollution Index method has a very high tolerance limit for pollution, because a water is declared heavily polluted if most of the measured parameter values are more than 63 times the value of water quality standard for its allotment.

\section{CONCLUSION}

The water quality of the Dendeng River tends to decline from the upstream to the middle and downstream zones. Dissolved oxygen (DO) levels in the upstream zone are higher than in the middle and downstream zones. The $\mathrm{pH}$ value fluctuates from the upstream, middle and downstream zones, but is still in the normal $\mathrm{pH}$ range (69). The concentration of BOD at several monitoring points in the middle and downstream zones range from 2.13 to $2.25 \mathrm{mg} / \mathrm{L}$, has exceeded the National Water Quality Standard (NWQS). Measured COD values ranged from $3.3 \mathrm{mg} / \mathrm{L}$ (upstream zone) to $13.1 \mathrm{mg} / \mathrm{L}$ (downstream zone). The average value of phosphate levels ranged from 0.14 to $0.33 \mathrm{mg} / \mathrm{L}$ and all of them in the middle and downstream zones have exceeded the NWQS. Based on the Pollution Index, the status of Dendeng River water is in good condition to lightly polluted with a Pollution Index value ranging from 0.6 to 1.52 . Parameters that contribute to Dendeng River pollution are DO, BOD, COD and phosphate. Overall, Dendeng River has a WQI value of 86.67 with good water quality status.

\section{REFERENCES}

Aa, A., So, F., \& Aa, A. (2006). Dynamics Of Limnological Features Of Two Man-Made Lakes In Relation To Fish Production. African Journal Of Biotechnology, 5(10), 1013-1021.

Alaerts, G., G, \& Santika, S. S. (1984). Metode Penelitian Air. Usaha Nasional.

Alam, M. J. B., Islam, M. R., Muyen, Z., Mamun, M., \& Islam, S. (2007). Water quality parameters along rivers. International Journal of Environmental Science \& Technology, 4(1), 159167. Retrieved from https://dx.doi.org/10.1007/bf03325974 10.1007/bf03325974

Effendi, H. (2003). Telaah Kualitas Air Bagi Pengelolaan Sumber Daya Dan Lingkungan Perairan. Penerbit Kanisius.

Jc, A., Fi, A., \& Yusuf, E. (2010). Physical And Chemical Parameters In Abattoir Wastewater Sample. The Pacific Journal of Science And Technology, 11(1), 640-648.

Jfn, A., \& Adi, G. (2009). Some Physical And Chemical Characteristics In Okpoka Creek. Research Journal Of Environmental And Earth Sciences, 1(2), 45-53.

Kehutanan, K. N. L. H. D. (2020). Kementerian Negara Lingkungan Hidup Dan Kehutanan. Rencana Startegis Tahun 2020-2024, Kementerian Negara Lingkungan Hidup Dan Kehutanan.

Lingkungan, K. N., \& Hidup. (2004). Penerbit Kementerian Negara Lingkungan Hidup. Status Lingkungan Hidup Indonesia.

Lingkungan, K. N., \& Hidup. (2008). Penerbit Kementerian Negara Lingkungan Hidup. Status Lingkungan Hidup Indonesia. 
Oa, A., Ok, A., Adeleye, E., \& Rk, Y. (2008). Seasonal Limnological Variation And Nutrient Load Of The River System In Ibadan Metropolis. European Journal Of Scientific Research, 23(1), 98-108.

Ok, A., Oa, A., \& Rk, Y. (2008). Seasonal Change In Physico-Chemical Parameters And Nutrient Load Of River Sediments In Ibadan City. Nigeria. Global Nest Journal, 10(3), 326-336.

Pesce, S. (2000). Use of water quality indices to verify the impact of Córdoba City (Argentina) on Suquía River. Water Research, 34(11), 2915-2926. Retrieved from https://dx.doi .org/10.1016/s0043-1354(00)00036-1 10.1016/s0043-1354(00)00036-1

Raja, P., Am, A., Elangovan, R., \& Palanivel, M. (2008). Evaluation Of Phisical And Chemical Parameters Of River Kaveri. Journal Of Environmental Biology, 29(5), 765-768.

Rawat, A., \& Joshi, G. K. (2019). Physicochemical And Microbiological Assessment Of Spring Water In Central Himalayan Region. Physicochemical And Microbiological Assessment of Spring Water In Central Himalayan Region, 191-218.

Rizza, R. (2013). Hubungan Antara Kondisi Fisik Sumur Gali Dengan Kadar Nitrit Air Sumur Gali Di Sekitar Sungai Tempat Pembuangan Limbah Cair Batik. Unnes Journal Of Public Health, 3(2), 1-10.

Sa, S., Es, H., \& Purba, I. (2008). Kualitas Air Sungai Code, Winongo Dan Gajahwong, Daerah Istimewa Yogyakarta. Jurnal Ilmu Tanah Dan Lingkungan, 8(2), 121-125.

Simonovic, S. P. (2002). Word Water Dynamic: Global Modeling Of Water Resources. Journal Of Environmental Management, 66, 249-267.

Uddin, M. G., Nash, S., \& Olbert, A. I. (2021). A review of water quality index models and their use for assessing surface water quality. Ecological Indicators, 122, 107218-107218. Retrieved from https://dx.doi.org/10.1016/j.ecolind.2020.107218 10.1016/j.ecolind .2020 .107218 